\title{
The methods used for the diagnosis and evaluation of scoliosis
}

\section{Ana-Maria VUTAN ${ }^{1}$, Erwin-Christian LOVASZ ${ }^{2}$, Mihaela AMARANDEI ${ }^{3}$, Valentin CIUPE ${ }^{4}$}

\begin{abstract}
In recent years there multiple studies have been carried out on early diagnosis of scoliosis on school and preschool children. The diagnosis and evaluation of scoliosis is done by carrying out X-rays. A protocol is implemented for tracking the evolution of a scoliosis which involves both clinical control and imaging (X-ray) every 6 months, until the end of the growth period of the child. Because investigations such as X-ray and CT, can have harmful effects on the child's growing body (recent studies have shown that X-ray affects the skin, eyes, hematopoietic tissue, gonads and may cause cancer), new methods for diagnosing and tracking the evolution in time were researched. The present paper tries to present the current methods used in the diagnosis and assessment of scoliosis evolution in time, pointing out the main advantages and disadvantages of each method. There are a few methods developed in recent years in Germany by Zebris Medical Gmbh (using mapping with ultrasonic digital equipment), in Canada by InSpeck (using three-dimensional mapping through digital image acquisition) but used on a small scale. The newly developed methods have the advantage of being non-invasive, painless, non-irradiating and they can be used regardless of health status or gender. Although medical technology has developed very rapidly in recent years, radiology remains the most common method of investigation used for scoliosis. Certainly, in the near future the methods presented in this paper could be used more widely, for the benefits arising from their use.
\end{abstract}

Key words: scoliosis, methods of investigation and evaluation, advantages, disadvantages.

\section{Rezumat}

În ultimii ani s-au realizat multiple studii privind diagnosticarea precoce a scoliozelor la școlari și preșcolari. Diagnosticarea și evaluarea unei scolioze se realizează în prezent prin efectuarea de radiografii. Există implementat un protocol de urmărire al scoliozelor care presupune efectuarea unui examen clinic și imagistic (radiografii) la fiecare șase luni, pe toată perioada de creștere a copilului. Deoarece investigațiile precum radiografiile (RX) și tomografia computerizata, pot determina efecte negative asupra corpului în creștere al copilului, s-au cautat noi metode de diagnosticare și urmărire a evoluției scoliozei ( studiile au arătat că radiația X poate afecta pielea, ochii, țesutul hematopoetic, gonadele și poate determina dezvoltarea cancerului). In ultimii ani au fost dezvoltate noi metode care sunt non-invazive, nedureroase, neiradiante dar care sunt utilizate la scară redusă. Lucrarea de față încearcă să prezinte metodele utilizate la ora actuală în diagnosticarea și urmărirea scoliozelor, punctând principalele avantaje și dezavantaje ale fiecăreia. Există noi metode dezvoltate, în ultimii ani, în Germania de către cei de la Zebris Medical Gmbh -echipamentul Zebris de mapare ultrasonică digitală, în Canada de către cei de la InSpeck Inc -sistemul InSpeck de mapare tridimensională prin preluare digitală de imagine. Noile metode dezvoltate au avantajul de a fi non-invazive, nedureroase, neiradiante pentru corpul copilului și acestea pot fi utilizate indiferent de starea de sănătate sau sexul celui investigat. $\mathrm{Cu}$ toate că tehnologia medicală s-a dezvoltat extrem de rapid în ultimii ani, în cazul scoliozelor radiologia rămâne metoda de investigare cea mai utilizată. Cu siguranță, în viitorul apropiat metodele prezentate în această lucrare vor putea fi utilizate și la scară mai largă datorită avantajelor rezultate din utilizarea lor. Cuvinte cheie: scolioza, metode de investigare și evaluare, avantaje , dezavantaje

\footnotetext{
${ }^{1}$ Student PhD, Mechatronic Department, Politehnica University Timisoara, Romania, anamariavutan@yahoo.com

${ }^{2}$ Professor, Dr. Ing. habil, Mechatronic Department, Politehnica University Timisoara, Romania

${ }^{3}$ University Assistant, Mechanic and Strength Materials Department, Politehnica University Timisoara, Romania.
}

${ }^{4}$ Lecturer, Dr. Ing., Mechatronic Department, Politehnica University Timisoara, Romania. 


\section{Introduction - Methods used for diagnostic and evaluation of scoliosis}

In recent years there has been an increase in the number of children with spine deformities, both among the school children and preschool children. Several studies have followed up the early diagnosis of various deformities such as kyphosis, lordosis or scoliosis. Orthopedic doctors, pediatricians, school doctors and parents should work together during early stages of child development in order to avoid that the evolution of the diseases causes dramatic postural changes that could lead to surgery.

Of all spine deviations, scoliosis can have a disabling evolution in time. Scoliosis is defined as a progressive deviation characterized by one or more lateral curvatures of the spine, visible in frontal plane, accompanied by the rotation of the vertebral bodies [1]. Scoliosis is divided into two main groups: non-structural (scoliosis attitudes) and structural scoliosis. In structural scoliosis there are some irreversible changes: the vertebrae are deformed as a taper and suffer a rotation around their vertical axis, due to which vertebral bodies are pushed to convex side, while the spinous processes are retained on the concave side, in this way the rib hump is formed of the thoracic convexity [2].

Orthopedic surgeons are the ones to establish the diagnosis of scoliosis. Besides clinical examination to confirm the scoliosis, an imaging examination is needed. Currently the examination can be achieved by X-ray, CT, MRI, Moiré topography and integrated shape imaging system (ISIS), computerized raster stereography [3].

Unfortunately some of these investigations subject the child's body to harmful radiation. Currently there are other possibilities to investigate and to monitor the evolution of scoliosis but these noninvasive devices are not widely used at the moment: thermography, mapping the three-dimensional digital image acquisition and digital ultrasonic mapping.

After confirming the diagnosis and establishing the stage of the disease, the doctor will decide over the treatment to be followed by the patient. Treatment can extend over several years, depending on the age of the child and existing deformations.

The evaluation is performed continuously until the end of the growing period. In Romania there is a protocol for following scoliosis that requires conducting clinical examination and X-ray examination every 6 months.

\section{Materials and methods}

Clinical examination aims at assessing alignment and posture (static test) and achieving a functional balance -muscular and articular- including the assessment of gait (dynamic examination).

The clinical examination reveals the localization, grade and numbers of non-physiological curvatures. In many rehabilitation departments, clinical examination is complemented by a set of photos of the person with scoliosis, made of front, rear and profile, in standing and flexion position. They are intended to track the patient's posture and thus effectiveness of treatment.

Clinical examination is followed by laboratory tests which are actually a medical imaging examination that involves taking global or sequential images, plane or pointed of the spine in the frontal and / or sagittal plane. At the moment the methods used for imaging examinations in the case of scoliosis are: classic radiology (X-Ray), computed tomography (CT), magnetic resonance imaging (MRI), Moiré topography, computerized raster stereography, optical scanning through system ISIS (Integrated Shape Imaging System), thermography., digital ultrasonic mapping (using Zebris devises) and mapping the three-dimensional digital image acquisition (using InSpeck system ) [4].

Radiological examination is still the most used method to investigate scoliosis. This consists in examining the body using X-ray radiation (X-rays) that impresses a photographic film. X-Rays are ionizing radiations that have the ability to penetrate the organic material and produce a photographic effect on a photosensitive surface. The absorbance differences in each tissue allow to obtain images composed of multiple shades of gray (absorbance areas allow a small amount of radiation to pass) [5]. The first exposure of the spine to X-ray is performed from the front and side, an X-ray of the entire spine, the iliac crest and the fist also (the last two for assessing bone age). This examination highlights the presents of the curvature / curvatures, indicating the top vertebra and the upper and the lower vertebrae, it can determine the etiology of the disease and it can give guidance over the treatment [1].

The measurements on X-ray, state the magnitude of the angle of curvature main and compensatory curves. The data obtained are of great importance for monitoring the evolution of scoliosis therapy and these measurements will be performed at each radiological control. Two methods are routinely used, introduced in radiology by Ferguson (1920) and Cobb (1948) that determine the value in degrees of the angle of curvature [6]. In Romania the Cobb angle for scoliosis is constantly used (it is considered the most objective). The Cobb's angle is calculated as follows: draw a tangent line to the upper plateau of the upper vertebra of the 
curvature and a tangent line to the lower plateau of the lower vertebra of the curvature. Perpendiculars drown on these lines describe a complementary angle that indicates the shift value of the spine [1].It is important to measure the Cobb angle using the same vertebra every time the patient is exposed to $\mathrm{X}$-ray. This is why it is recommended that the same person should perform the measurements of the Xray.

On X-ray the examiner can also measure vertebral rotation. This technique was proposed by Nash and Moe. Thus there are five degrees of rotation (from grade 0 to grade IV) based on symmetry and fairness vertebral pedicles toward the side edges of the top vertebrae [1].

The evaluation of a child with scoliosis is performed continuously until the end of the growing period. A progressive scoliosis involves making numerous X-rays that can expose the patient to overexposure. Tracking the evolution of scoliosis requires clinical and imaging examination every 6 months.

The radiological examination for scoliosis presents a number of advantages such as: objective information on the shape and position of the spine, allows us to do an objective measurements of the angle / angles curve / curves (Cobb angle and the rotation of the vertebrae), short time to take over and analyze the images and also the low cost of the investigation.

The disadvantages of radiological examination are: they allow a two-dimensional image of the spine, which offers us only the basic information over the deviation of the spine and the fact that X-Ray are harmful for the human body, especially in the case of children. The Röentgen radiation causes changes in the structure of DNA and increase the risk of cancer [1].

Investigation by CT and / or MRI is used for obtaining more detailed information of the disease. These two methods are partially invasive, due to the penetrated radiation effect on human body [4].

Computer tomography, (CT scanner) also uses Röentgen radiation ( $\mathrm{X}$ radiation) and consists in taking images of the subject in horizontal and vertical section, resulting in a $3 \mathrm{D}$ image. The advantage of using the CT scanner is a more detailed image of the spine, we can see elements that do not appear or cannot be detected in a classic $\mathrm{X}$-Ray image. There are some disadvantages such as: the image acquisition is performed in the supine position (we cannot measure correctly the Cobb angle), storing and processing of the images implies quite long time, high costs of the investigation and the harmfulness of $\mathrm{X}$ radiation ( e.g., a classic chest radiography corresponds to 3 days of annually exposure or $0.02 \mathrm{mSv}$, while a CT chest scanner corresponds to 3.6 years of natural exposure, or $8 \mathrm{mSv}$ ) [1].

Magnetic resonance imaging (MRI) uses a radio frequency radiation field in a magnetic field. MRI scanners use a large magnet that excites the hydrogen atoms of the vertebrae, spinal cord, muscles and ligaments at the spine and in this way gets a 3D image. The obtained imagine shows a fine contrast and offers information about bones and soft tissues around the spine. This investigation has a less harmful effect on the human body. The MRI investigation disadvantages are: it takes a longtime to pick-up and analyzes the information, the examination is done in supine position and the price is high.

Moiré topography is an optical mapping method. There are three types of Moiré systems: the "shadow" system, the projection system and hologram system. The Moiré pattern is obtained by directing a high-intensity light through a grating on the back of the subject [7]. Thus, asymmetries of the back are observed as deviations in the form of fringe pattern from left to right. The advantages of this method: it's a simple, non-invasive, noncontact method, it creates a 2D representation of the spine with the possibility to deducted to 3D image and points the back's asymmetries. It is a good method to quantify scoliosis because it is more sensitive than the clinical methods such as the bending test. The major disadvantage of this method is the false-positive effect given by an asymmetry of the shoulder blades that can be independent of the position of the spine. Also there is no correlation between the side deviation of the spine measured on X-Ray and differences between lines, measured by Moiré topography.

Computerized raster stereography designs on the surface of the torso of a grid of perpendicular lines. Depending on the distortions that the lines have on the back of the person we can analyze the incorrect posture of the shoulders, spine, shoulder blades, ribs and pelvis. This method is very simple, noninvasive and easy to use for screening children [7]. Unfortunately the method does not allow quantitative measurements.

The ISIS optical scanning system allows the dynamic study of deformities of the spine. The system uses beams of light that scroll on the investigated surface of the back, in different points (C7, D8, D12 and the posterior iliac spines). The detected distortions give a 3D representation of the surface skin of the back. This is a simple, effective and non-invasive method and it can invert a 3D image of the torso but without quantitative determinations. It has the disadvantage of the cost.

Thermography has begun to be successfully used in recent decades. Thermography investigation is a 
method increasingly used in medical applications because it is non-invasive, non-contact, and painless, the human body is not radiated and it can be applied without restriction to all categories of patients regardless of age, sex or health status. Thermo graphical technique is based on the property of bodies to emit radiation in the infrared range. Thermal imaging equipment that operates on the principle of conversion is based on infrared radiation in digital image output signal. Currently thermography is limited to taking still or dynamic images that seek only local variation and / or temperature over time [8]. As an investigation method, thermography requires a patient preparation of approximately 30 minutes to remove artifacts given by the wearing of clothes, a constant temperature of the room and dimness room assessment. The investigation can be done whenever needed regardless of the patient's age or health status. Thermography is used in some clinics in the country for early diagnosis of newborn scoliosis. The main disadvantage for thermography is the false-positive effect in case of a scoliosis attitude. In Figure 1 a lumbar scoliosis is shown. The image was taken with a thermal camera in the Department of Material Strength of the Politehnica University Timisoara.

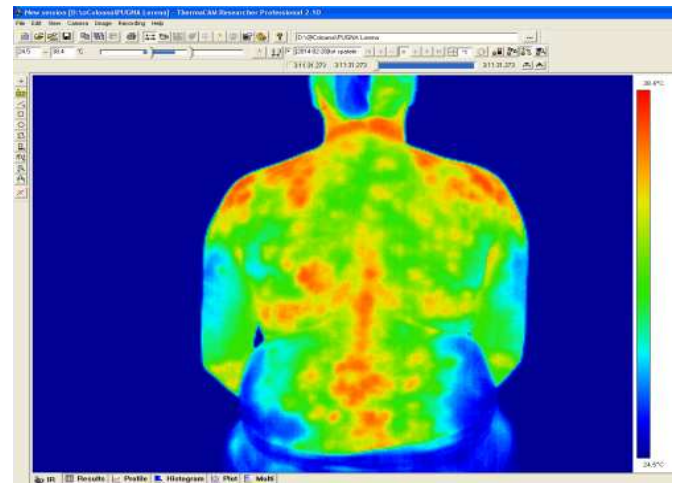

Figure 1. Scoliosis seen with a thermal camera (FLIR $\mathrm{A} 40 \mathrm{M}$ ) (The source: picture taken in the Mechanics and Strength Materials Department, University Politehnica Timisoara)

Nowadays there is a tendency to replace invasive methods with non-invasive ones using CCD cameras, computerized raster stereography, ultrasounds or laser sources. All these methods are computer assisted, in order to obtain, accumulate and process the measurements data, allowing realtime monitoring of the subject [4]. These are the reasons for the increasing number of devises used in scoliosis evaluation, such as: Zebris Medical Gmbh from Germany produces spinal analysis and monitoring devices based on ultrasounds,
Cyberware produces body laser scanning devices, InSpeck Inc produces computerized raster stereography body scanning devices [7].

Mapping with ultrasonic digital equipment such as Zebris (designed by Zebris Medical Gmbh) is based on measuring the 3D coordinates of each vertebra [4], using a test indicator (pointer) to point the spinous processes of the vertebrae from C7 (the last cervical vertebra) to S1 (first sacral vertebra) as it is shown in figure 2. Each point is showed in 3D and coordinates using the triangulation method. The software of the equipment memorizes and processes the data, thus enabling 3D visualization of the spinal posture figure 3 .

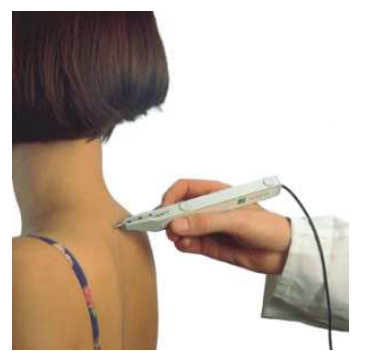

Figure 2. The use of indicator to point the spinous processes of the spine. (The source: Mateas M., et al., 2007)

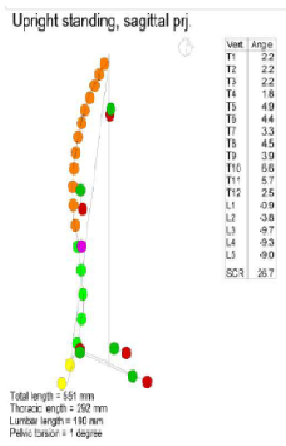

Figure 3. Spine medical report (The source: Mateas M., et al., 2007)

This method of evaluation of scoliosis is developed in recent years in response to the need to use equipment less harmful and allows a 3D visualization of the spine. The advantage of using this equipment is the possibility to analyze mobility and coordination of the spine. The disadvantages are: the long time for data acquisition (from the time to start scoring with Pointer, the patient must hold the position until the end of the operation, this means 10 minutes) and longer processing times. Another disadvantage is as well the high cost of the system.

Three-dimensional mapping through digital image acquisition using InSpeck system ( designed by 
InSpeck Inc in Canada) is an optical investigating method, non-invasive, non-contact which is based on taking pictures from different angles. After the pictures are taken, they are joined together using a special software, providing images 3D of the human body. InSpeck technology uses 3 to 6 Capture digital cameras (Fig.4) that can show both the geometry of the human body and very fine colors and textures in less than two second.

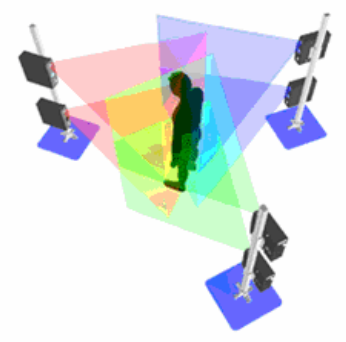

Figure 4. Capture digital cameras of the InSpeck (The source: Gugoasa G.A.,2010)

This measurement system allows the curvatures visualization, simulation and animation of the muscle groups (Fig. 5)

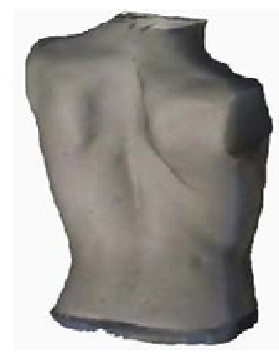

Figure 5. The image shown by the In Speck system (in The Mechatronics Departament of University Politehcica Timisoara. (The source: Gugoasa G.A., 2010)

This type of investigation has multiple advantages: it is non-invasive, non-contact, shows 3D geometry of the human body and the time for acquisition is extremely short [10]. This method can also help the patient to realize better the body position in space and perceive the changes taking place at the shoulders, shoulder blades, ribs and pelvis.The major drawback is the rather long processing time, requiring complicated procedures to unite all pictured. Also the high cost of the system is one of the disadvantages that we can mention.

The last two investigation methods, mapping with ultrasonic digital mapping and three-dimensional digital image acquisition, are used mainly for assessment of the scoliosis evaluation.

Depending on the outcome of investigations, the treatment of scoliosis is established. There is a standardized protocol (proposed by Stagnara) depending on the severity of scoliosis: from $0^{\circ}-30^{\circ}$ Cobb angle physical therapy is indicated, from $30^{\circ}$ $50^{\circ}$ Cobb angle physiotherapy and orthopedic treatment (corset) are indicated, over $50^{\circ} \mathrm{Cobb}$ angle surgery is indicate [1]. If the treatment of scoliosis requires treatment through physical therapy with or without wearing an orthopedic brace, the physical therapist will decide the optimal method to stop the evolution and if possible to correct the deviation of the spine.

\section{Discussion}

Diagnosis of scoliosis involves performing a clinical examination and a set of X-rays. Subsequently diagnosed scoliosis follows therapy according to Stagnara protocol. Such children with scoliosis are irradiated with x-rays every six months to see the evolution. This protocol is still used in Romania in almost all pediatric orthopedic centers and medical rehabilitation centers.

$\mathrm{X}$-ray was and remains for the moment the most widely used method to diagnosis the scoliosis. Due to the negative effects of the repeated irradiation on the human body [1], numerous research centers have tried to develop new methods of investigation that can be used in a safe manner in terms of children's health [9].

Systems like Zebris or InSpeck were designed to evaluate the posture of the spine. They are still used on a small scale but because of the advantages they present in scoliosis evaluation may be recommended for a wider use. They can be used to determine the correct and complete spinal scoliosis in space, being able to calculate even the vertebral rotation [7].

At international scale, there is a tendency to replace the contact methods with non-contact methods, using CCD cameras, computerized raster stereography, ultrasounds or laser sources. All these methods are computer assisted, in order to obtain, accumulate and process the measurement data, allowing real-time monitoring of the subject [7].

\section{Conclusions}

In recent years the scoliosis is more common in school and preschool children. Early diagnostic plays an essential role in the evolution of this deviation in time. According to the protocol, the child with scoliosis is submitted every six months to clinical and imaging investigation [1]. X-Ray is the first choice for monitoring the evolution of scoliosis at this moment but that only brings us basic information about the deviation [2] and it has been shown it's harmfulness on the human body [1]. Now scientists try to develop new methods of investigation and monitoring for scoliosis without 
negative effects on the examined human body. As well as new emerging methods can be used successfully. The newly developed methods (mapping the three-dimensional digital image acquisition, digital ultrasonic mapping, thermography, ISIS) have the advantage of being non-invasive for the children body and they can be used no matter the state of health or gender. It is also important that the new devices will restore all the parameters to be followed in the evaluation of scoliosis, including vertebral rotation and therefore they must render 3D images. For sure in the near future these methods will be further developed in order to be widely used. 10

\section{References}

1. Jianu M. (2010). Scolioza pediatrica, Bucuresti, Pro Editura si Tipografie.

2. Lehnert-Schroth C. (2007). Three-dimensional treatment for scoliosis, California, USA.

3. Vacarescu V., Lovasz E., Margineanu D. (2008). The method for the evaluation of spinal column, Annals of DAAAM\&amp, Proceedings.

4. Lovasz E., Mateas M., Mircea M. (2005). Determination of the the Human Spine Geometry with CCD-cameras, Humboldt Symposium, Timisoara, Romania.

5. https://ro.wikipedia.org/wiki/Radiografia (10.15.2016)
6. Pana I., Vladareanu M., Roventa N., Mihaita I. (2000). Radiologie I, Editura Didactica si Pedagogică, București.

7. Mateas M., Vacarescu V., Lovasz E., Nemes I.D.A., Mircea M. (2007). About a new methodfor the 3D determination of the human spine geometry, 12thIFTMM World Congress, Besançon, France.

8. Amarandei M. (2013). Contributii privind implementarea investigatiei termografice in cercetarea din domeniul tehnic si medical, Editura Politehnica, Timișoara.

9. Benameur S. (2004). Reconstruction 3d biplanaire non supervisee de la colonne vertébrale et de la cage thoracique scoliotiques par modélestatistiques, Montrél, Ecole de Tehnologie Supérieure.

10. Gruescu C., Bodea R., Garaiman A., Costache M., Lovasz E. (2008). Relative rotation angle between spinal vertebrae using complex shape Markers. Annals of the Oradea University, Fascicle of Management and Technological Engeneering, Volume VII. 